\title{
Analysis of seed protein diversity in Cicer arietinum L. genotypes with different seed coat colour using SDS-PAGE
}

\author{
M. Chittora ${ }^{1^{*}}$, A. Sukhwal ${ }^{2}$, Chandraveer ${ }^{1}$ and G. Verma ${ }^{3}$ \\ ${ }^{1}$ Department of Dairy and Food Microbiology, College of Dairy and Food Science Technology, Maharana Pratap Uni- \\ versity of Agriculture and Technology, Udaipur- 313001(Rajasthan), INDIA \\ ${ }^{2}$ Department of Molecular Biology and Biotechnology, Rajasthan College of Agriculture, Maharana Pratap University of \\ Agriculture and Technology, Udaipur-313001(Rajasthan), INDIA \\ ${ }^{3}$ Department of Zoology, Government Meera Girls College, Udaipur- 313001 (Rajasthan), INDIA \\ *Corresponding author. E-mail: mnshchittora@yahoo.co.in
}

Received: February 10, 2016; Revised received: February 5, 2017; Accepted: April 11, 2017

\begin{abstract}
SDS-PAGE technique was used for the study of seed protein polymorphism among three genotypes of Cicer arietinum with different seed coat colour. A total of 24 polypeptide bands were recorded. Out of these 20 were common among all three genotypes and $4(16.66 \%)$ were polymorphic. The data analysis using UPGMA clustering revealed that genotypes with C2 (dark brown) and C3 (black) were closer as compared to genotype with C1 (light brown) coat colour. Jaccard similarity coefficient value ranged from 0.87 to 0.92 . The similarity matrix was subjected to UPGMA clustering to generate dendrogram. The most closely revealed genotypes were C2 (dark brown) and C3 (black) with the highest similarity index 0.92 whereas, C1 (light brown) showed minimum similarity index with C3 (black) genotype 0.87 . Each of three genotypes of $C$. arietinum had some polypeptide bands which were peculiar to them only. This enabled distinguishing all three genotypes on the basis of specific polypeptide fragments using SDS -PAGE analysis.
\end{abstract}

Keywords: Cicer arietinum, Genotype, Genetic Markers, SDS-PAGE

\section{INTRODUCTION}

Chickpea (Cicer arietinum L., $2 \mathrm{x}=2 \mathrm{n}=16$ ) belongs to the family Fabaceae. The genus Cicer L. comprises 49 taxa with 40 wild perennials, 8 wild annuals and one annual cultivated species (Toker et al., 2014; Smýkalet al., 2015). Chickpea is the second most important food legume in the worldin terms of area (13.5 million hectares) and production (13.1 million) tons in the 2013 after beans (FAOSTAT, 2016). Colour and pattern of seed coat are basicphenotypic features often used to distinguishgenotypes of higher plant species (McCleanet al., 2002). Control of phenotypic characteristics suchas seed coat pattern and colour by specific genehave been identified in a number of plant species(Acamporaet al., 2007). These genes might exhibit epistatic interaction with other genes which may define many seed coat colours and patterns within the species.

Genetic markers such as morphological traits, biochemical characteristics (isozyme, protein profiles) and DNA based molecular markers are powerful tools for the analysis of genetic diversity and relatedness among genotypes, species and large populations of plants. Although, morphological trait can be used for assessing genetic diversity but it is often influenced by the environmental factors (Siddiqui and Naz, 2009). Biochemical markers such as proteins and isozymes have served as an important tool todetect genetic relationships in plants (Mukhlesur et al., 2004). Protein polymorphism serves as genetic markers as they are direct products of active genes and are quite polymorphic and generally heritable (Gepts, 1990). The polymorphism observed in the protein profiles reflects the changes in the active part of the genome. Although protein polymorphism can be analysed through a variety of techniques, polyacryl amide gel electrophoresis (PAGE) is generally favored technique for rapid analysis (Fergusan and Grabe, 1986; Smith and Smith,1986; Raymond et al., 1991) due to its validity and simplicity for describing genetic variations (Ahmad and slinkard, 1992). This technique has been used effectively to decipher genetic diversity among/between genotypes in different plant species (Cook, 1984; Mukherjee and Datta, 2008).

In case of $C$. arietinum isozyme polymorphism among its natural populations (with different seed coat colour has been reported. The present investigation was undertaken to study the seed protein polymorphisms among three genotypesof $C$. arietinum with different seed coat colourusing SDS-PAGE. 


\section{MATERIALS AND METHODS}

Plant materials: Three genotypes of $C$. arietinum consisting of different seed coat colour (Light brown, dark brown and black) were chosen for the present investigation. For Protein extraction seeds were collected from the field grown plants, maintained in the pots at Department of Biotechnology, MLSU, Udaipur,India.

Extraction of seed proteins: In this investigation, Seeds $(1.0 \mathrm{~g})$ were ground to fine powder using 10.0 $\mathrm{ml}, 0.1 \mathrm{M}$ phosphate buffer $(\mathrm{pH}=7.0)$ containing $\beta$ - mercaptoethanol $(10 \mathrm{mM})$ andPhenylmethaneSulphonylfluoride $(2.8 \mathrm{mM})$. Theextract was centrifuged at 10,000 rpm for 15 minat $4^{\circ} \mathrm{C}$. The supernatant was again centrifugedat $10,000 \mathrm{rpm}$ for $10 \mathrm{~min}$ at $4^{\circ} \mathrm{C}$. The resultingsupernatant was used as protein sample.

Determination of protein concentration: The concentrations of proteins were determined spectrophotometrically using the Bradford method (Bradford, 1976).

Sample application and gel electrophoresis: Protein sample was mixed with $4 \mathrm{X}$ gel loadingdye to make its final concentration of $1 \mathrm{X}$ in mixtureand was heated at $95^{\circ} \mathrm{C}$ in water bath for $10 \mathrm{~min}$.prior to loading. Protein sample $(100 \mu \mathrm{g})$ wasloaded in each lane. Protein molecular weightmarker (Bangalore Genei, India) was used asreference. Protein samples were electrophoresedat $8 \mathrm{~V} / \mathrm{cm}$ for about $4 \mathrm{~h}$ at constant current. Preparative gel was visualized by staining withCoomassie Brilliant Blue R-250.

Data analysis: Gels were placed on a white light transilluminator and photographed. The polypeptide bands wereanalyzed using UVIBandMap software.

\section{RESULTS AND DISCUSSION}

The total seed protein extracts of all three genotypes (light brown, dark brown and black) when subjected to SDS-PAGE analysis revealed significant variation in polypeptide banding pattern (Fig. 1). Bands with same mobility were considered asidentical fragments, regardless of their staining intensity. A total of 24 polypeptide bands wererecorded (Table 1). The size of these polypeptide bands ranged from $20.89 \mathrm{kDa}$ to $117.46 \mathrm{kDa}$. Out of these polypeptide bands 20 were common among all three genotypes and 4 bands were polymorphic.

Each of three genotypes of Cicer arietinum had one polypeptide band which were peculiarto them only. $\mathrm{C} 1$ (Light brown) genotype had 1 specific polypeptide bands $(23.47 \mathrm{kDa})$ whichwere absent in other two (Dark Brown and Black) genotypes. Polypeptide bands of the molecular weight $114.24 \mathrm{KDa}$ were present only in C2 (Dark brown) genotype, whereas polypeptideband of molecular weight $117.46 \mathrm{kDa}$ was present only in C3 (black) genotype. The phylogenetic analysis based on protein pattern placed C2 (Dark brown) and C3 (black) genotypes very close to each other.
Jaccard's similarity coefficient value ranged from 0.87 to 0.92 (Table 2). The similarity matrix was subjected to UPGMA clustering to generate dendrogram (Fig. 2). Lowest Jaccard's similarity value represents maximum diversity. Genotypes with C1 (Light brown) and C3 (black)were more diverse as compared to genotype with C2 (Dark brown) seed coat colour. The most closely genotypes C2 (Dark brown) and C3 (black) with the highest similarity index 0.92 , whereas $\mathrm{C} 1$ (light brown) showed minimum similarity index with C3 (black) genotype (0.87)

Seed protein analysis using SDS-PAGE isparticularly considered as a reliable techniquebecause seed storage proteins are highlyindependent of environmental fluctuations. Thehigh stability of seed protein profile and its additivenature makes it a promising tool for distinguishing genotypes of particular plant species. Therefore, in the present studies SDS-PAGE technique wasemployed for analysis of seed protein diversity inC. arietinumgenotypes with different seed coatcolour (light brown, dark brown and black). SDS-PAGE technique has been successfully applied in many different plant species to estimate genetic diversity and phylogenetic relationship among genotypes.

Genetic diversity for some nutritive traits of chickpea (C. arietinum L.) from different regions of kosova were analyzed and significant difference were observed in mineral contents among genotypes (Aliu et al., 2016). Similarly, Arefian et al. (2014) have showed significant change in protein profiling and amount of protein in chickpeas in response to salinity stress during early stages of seedling growth. Singh et al. (2015) performed characterization of seed storage

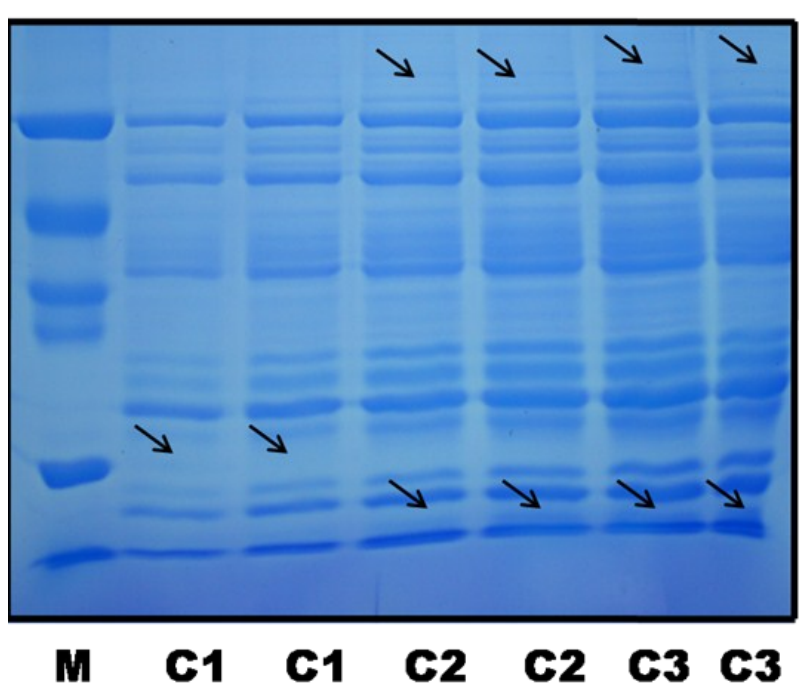

Fig. 1. Comparative evaluation of protein profiles of three genotypes (Light Brown, Dark Brown and Black) of Cicer arietinum $L$.

$\mathrm{M}=$ Molecular Weight Marker

$\mathrm{C} 1=$ Light Brown Colour Genotype

$\mathrm{C} 2=$ Dark Brown Colour Genotype

C3=Black Colour Genotype 
M. Chittora et al. / J. Appl. \& Nat. Sci. 9 (2): 706 - 709 (2017)

Table 1. Comparative Evaluation of protein profiles among three genotypes of Cicer arietinumL. with different seed coat colour.

\begin{tabular}{ccccc}
\hline S. No. & Molecular Weight (kDa) & C1 & C2 & C3 \\
\hline 1 & $\mathbf{1 1 7 . 4 6}$ & - & - & + \\
2 & 115.85 & + & + & + \\
3 & $\mathbf{1 1 4 . 2 4}$ & - & + & + \\
4 & 113.49 & + & + & + \\
5 & 110.96 & + & + & + \\
6 & 89.13 & + & + & + \\
7 & 75.86 & + & + & + \\
8 & 66.07 & + & + & + \\
9 & 61.66 & + & + & + \\
10 & 57.54 & + & + & + \\
11 & 53.70 & + & + & + \\
12 & 50.12 & + & + & + \\
13 & 46.77 & + & + & + \\
14 & 44.67 & + & + & + \\
15 & 41.69 & + & + & + \\
16 & 38.02 & + & + & + \\
17 & 34.67 & + & + & + \\
18 & 30.90 & + & + & + \\
19 & 29.51 & + & + & + \\
20 & 25.70 & + & - & + \\
21 & $\mathbf{2 3 . 4 7}$ & + & + & + \\
22 & 22.91 & + & + & + \\
23 & $\mathbf{2 1 . 4 2}$ & + & + & + \\
24 & 20.89 & & + & + \\
\hline & & + & + & + \\
\hline
\end{tabular}

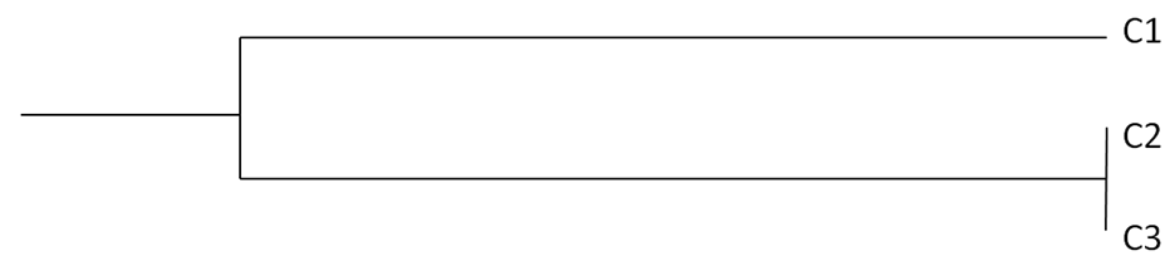

C1

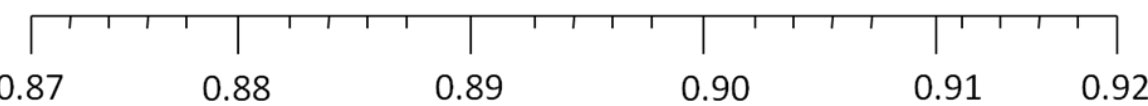

Fig. 2. Dendrogram obtained from polypeptide bands analysis using UPGMA demonstrating relationshipamong three genotypes of Cicer arietinumL. with different seed coat colour.

proteins of chickpea using 2D electrophoresis coupled with mass spectrometry, a total of 600 protein spots were detected. In-gel protein expression patterns revealed that three protein spots as upregulated and three other as downregulated. Likewise, Gupta et al. (2016) have also reported significant genetic diversity in chick pea using seed protein profiling.

In wheat, Siddiqui and Naz (2009) showed 5.0-84.0\% polymorphism among 10 genotypes. Similarly, Khan et al. (2010) observed 0.0-60.0\%genetic polymorphism with in twenty genotypes of walnut. Using SDSPAGE, Inamullah et al.(2010) have showed 0-80\% polymorphismamong eleven genotypes of Oryza sativa. In Capsicum sp., 0-100\% polymorphism was observedin nineteen genotypes (Akbar et al., 2010) whilein Kabuli Chickpea genotypes significant polymorphism was reported (Hameed et al., 2009). Similarly, Chittora and Purohit (2012) showed 5.0$11.0 \%$ polymorphism among three genotypes of Abrusprecatorius. Present studies carried out with three genotypes of $C$. arietinum revealed 8.0-13.0\% polymorphism. SDS-PAGE analysis provided strong basis for the discrimination of genotypes on the basis of specific polypeptide fragments. 
Table 2. Jaccard's similarity coefficient values of three genotypes of Cicer arietinum L. with different seed coat colour.

\begin{tabular}{cccc}
\hline & $\mathrm{C} 1$ & $\mathrm{C} 2$ & $\mathrm{C} 3$ \\
\hline $\mathrm{C} 1$ & 1.000 & & \\
$\mathrm{C} 2$ & 0.880 & 1.000 & \\
$\mathrm{C} 3$ & 0.870 & 0.920 & 1.000 \\
\hline
\end{tabular}

\section{Conclusion}

The importance of plant genetic diversity is now being recognized as a specific area since exploding population with urbanization and decreasing cultivable lands are the critical factures contributing to food insecurity in developing world. It provides opportunity for plant breeders to develop new and improved cultivars with desirable characteristics. In conclusion, electrophoretic polypeptide bands of seed storage proteins can provide a potent tool to estimate genetic variation and relation among germplasm. The specific band of seed storage protein profiles may be used as markers for identification of the varieties.

\section{REFERENCES}

Acampora, A.,Ciaffi, M., Pace, C.D.,Paolacci, A.R. and Tanzarella, O.A. (2007). Pattern of variation for seed size traits and molecular markers in Italian germplasm of Phaseolus coccineusL.Euphytica., 157: 69-82

Ahmad, F. and Slinkard, A.E. (1992). Genetic relationships in the genus CicerL. as revealed by polyacrylamide gel electrophoresis of seed storage proteins.Theor. Appl. Genet., 84: 688-692

Akbar, A., Ahmed, H., Ghafoor, S. and Khan, A.I. (2010). Phylogeny and genetic diversity studies in Capsicum using seed storage proteins.Curr. Res. J. Biol. Sci., 2 (4): $250-252$

Aliu, S., Kaul, H.P., Rusinovci, I, Mayrhofer, V.S., Fetahu, S. and Zeka, D. (2016). Genetic diversity for some nutritive traits of chickpea (Cicer arietinum L.) from different regions in Kosova. Turkish J. Field crops, 21 (1) $156-161$

Arefian, M., Vessal, S. and Bagheri, A. (2014). Biochemical changes and SDS-PAGE analyses of chickpea (Cicer arietinum L.) genotypes in response to salinity during the early stages of seedling growth. J. Biol. Environ. Sci., 8 (23): 99-109

Bradford, M.M. (1976). A rapid and sensitive method for the quantitation of microgram quantity of protein utilizing the principle ofprotein-dye binding. Anal Biochem., 72: 248-254

Chittora, M. and Purohit, S.D.(2012). Optimization of SDSPAGE Conditions and Analysis Of Seed Protein Diversity In Abrus Precatorius Genotypes With Different Seed Coat Colour. Int. J. Life Sci.Biotech. Pharma Res., 1 (2): 268-277

Cook, R.J. (1984). The characterization and identification of crop cultivars by electrophoresis. Electrophoresis., 5: 65-72

Fergusan, J.M. and Grabe, D.F. (1986). Identification of cultivars of perennial rye grass by SDS-PAGE of seed
proteins.CropSci., 26:170-176

Food and Agricultural Organization of the United Nations. (2013). FAO Statistical Databases. Available at http:// faostat.fao.orgl FAO, Rome.

Gepts, P. (1990). Genetic diversity of seed storage proteins in plants.Plant PopulGenet, Breeding and Genet Resour., 64-82

Gupta, D., Chellapila, B. and Ranjan, R. (2016). Genetic diversity analysis of chickpea (Cicer arietinum L.) using seed protein profiling. Int. J. Innovative Res. multidisciplinary field, 2 (9): 1-10

Hameed, A., Shah, T.M., Atta, B.M., Iqbal, N., Haq, M.A. and Ali, H. (2009). Comparative seed storage protein profiling of kabuli chickpea genotypes. Pak. J. Bot., 41 (2): 703-710

Inamullah., Khan, I.A., Ahmed, H., Ghafoor, S.,Gul, S., Muhammad, I. and Ilyas, M. (2010). Seed storage protein profile of rice varietiescommonly grown in Pakisthan. Asian J of Agricultural sciences, 2 (4): 120-123

Khan, M.W., Khan, I.A., Ahmed, H., Ali. H., Gafoor, S., Afzal, M., Khan, F.A., Shah, M. and Afridi, S.G. (2010) Estimation of genetic diversity in walnut. Pak. J. Bot., 42 (3): 1791-1796

McClean, P.E., Lee, R.K., Otto, C., Gepts, P. and Bessett, M.J. (2002). Molecular and phenotypic mapping of genes controlling seed coat pattern and colour in common bean (Phaseolus vulgaris L.).The J.Heridity., 93: 148-152

Mukherjee, M. and Datta, A.K. (2008), Evaluation of genetic diversity in five species of Ocimumby SDSPAGE.IndianJ. Genet. Plant Breed, 68: 212-214

Mukhlesur, R.M., Hirata, Y. and Alam, S.E. (2004). Genetic variation within Brassicarapacultivars using SDSPAGE for seed protein and isozyme analysis.J. Biol. Sci., 4(2): 234-238

Raymond, J., Inquello, V. and Azanza,J.L. (1991). The seed protein of sunflower: comparative studies of cultivars. Phytochemistry, 30: 2849-2856

Siddiqui, M.F. and Naz, N. (2009). Protein landmarks for diversity assessment in wheat genotypes".African $J$ Biotech., 8 (9): 1855-1859

Singh, P.K., Shrivastava, N., Chaturvedi, K., Sharma, B. and Bhagyawant, S. (2015). Characterization of seed storage proteins from chickpea using 2D electrophoress coupled with mass spectrometry. Biochem res int., 1: 1-6

Smith, J.S.C. and Smith, O.S. (1986). Environmental effects on Zein Chromatograms of maize inbred lines revealed by reversed-phase high performance liquid chromatography. Theor.Appl. Genet., 71: 607-612

Smýkal, P., Coyne, C.J., Ambrose, M.J., Maxted, N., Schaefer, H., Blair, M. W., Berger,J., Greene, S. L., Nelson, M., Besharat, N., Vymyslicky, T., Toker, C., Saxena, R.K., Roorkiwal, M., Pandey, M. K., Hu, J.,. Li, Y.H., Wang, Guo, Y., Qiu, Li., Redden, R.J., and Varshney, R. K. (2015). Legume crops phylogeny and genetic diversity for science and breeding. Critical Reviews in Plant Sciences, 34 (1-3), 43-104

Toker, C., Uzun, B., Ceylan, F. O. and Ikten, C. (2014). Chickpea. In: Alien Gene Transfer in Crop Plants, A. Pratap and J. Kumar Eds., Volume 2, Springer, Dordrecht, Pp. 121-151 